ks. dr hab. Robert Tyrata, prof. UPJPII

Uniwersytet Papieski Jana Pawta II w Krakowie

Akademia Muzyczna w Krakowie

\title{
Liturgia sercem pisana! \\ Ks. prof. dr hab. Jan Józef Janicki i jego Mistrzowie
}

Skoro „liturgia jest źródłem i szczytem życia Kościoła” (KL 10), jak naucza nas Sobór Watykański II, to z niej wszystko wypływa i do niej wszystko zdąża. O takim właśnie rozumieniu tej „cząstki” życia Kościoła niezwykle przekonany jest nasz Jubilat - ks. prof. Jan Józef Janicki - który dla piękna tej szaty Kościoła, jaką jest liturgia, poświęcił swoje naukowe i życiowe dociekania, dlatego można już na samym początku powiedzieć o nim, że lit u rgi ię sercem p is ze! Ale zacznijmy od samego początku.

Urodził się 27 października 1946 r. w Słomnikach. Studia filozoficzno-teologiczne odbył w latach 1964-1970 w Wyższym Seminarium Duchownym w Kielcach. Święcenia kapłańskie przyjął w bazylice Grobu Bożego w Miechowie, wraz z czterema kolegami, 14 czerwca 1970 r. W latach 1971-1972 studiował liturgikę w Instytucie Teologii Pastoralnej KUL w Lublinie. W latach 1972-1977 odbył studia specjalistyczne z zakresu liturgiki w Pontificio Istituto Liturgico w Rzymie. W 1974 r. uzyskał magisterium w Papieskim Instytucie Liturgicznym w Rzymie, zaś 5 maja 1977 r. doktorat teologii liturgii na podstawie rozprawy doktorskiej: Le orazioni „super oblata" del ciclo "de tempore" secondo il „Missale Romanum” di Paolo VI. Avviamento ad uno studio critico-teologico, napisanej pod kierunkiem o prof. Burkharda Neunheusera w Pontificio Istituto Liturgico w Rzymie. 8 grudnia 1992 r. habilitował się na Wydziale Teologicznym Akademii Teologii Katolickiej w Warszawie. Przedstawił wówczas pracę pt. Misterium paschalne w Mszale Rzymskim Pawta VI. Studium liturgiczno-teologiczne euchologii okresu wielkanocnego. Dyplom uzyskał 21 czerwca 1993 r. 7 maja 1997 r. został mianowany docentem w Wydziale Historii Kościoła Papieskiej Akademii Teologicznej w Krakowie. 20 września 2000 r. powołany na stanowisko profesora uczelnianego w Papieskiej Akademii Teologicznej w Krakowie. 16 listopada 2004 r. uzyskał tytuł naukowy profesora nauk teologicznych. Przedstawił wówczas książkę profesorską pt. Kultury antyczne $w$ liturgii chrześcijańskiej. 1 października 2005 r. uzyskał stanowisko profesora nadzwyczajnego nauk teologicznych na Wydziale Historii Kościoła Pa- 
pieskiej Akademii Teologicznej w Krakowie. 22 listopada 2011 r. uzyskał stanowisko profesora zwyczajnego nauk teologicznych na Wydziale Historii i Dziedzictwa Kulturowego Uniwersytetu Papieskiego Jana Pawła II w Krakowie ${ }^{1}$.

Jego praca duszpasterska i naukowa przestawia się równie imponująco. W latach 1977-1982 pracował w duszpasterstwie akademickim oraz w wydziale duszpasterskim (referat liturgiczny) kurii diecezjalnej w Kielcach. W latach 1980-1981 prowadził wykłady z liturgiki w Wyższym Seminarium Duchownym w Łodzi. W latach 1982-89 posługiwał jako proboszcz (Ryczów k. Ogrodzieńca). W latach 1985-1988 wykładał liturgikę w Studium Teologicznym dla Świeckich w Olkuszu, w Studium Teologiczno-Pastoralnym dla Księży oraz Studium Katechetycznym dla Świeckich w Kielcach. W latach 1986-1994 prowadził wykłady zlecone w Instytucie Liturgicznym Papieskiej Akademii Teologicznej w Krakowie. W roku 1986 otrzymał nominację na egzaminatora z liturgiki księży wikariuszy diecezji kieleckiej. Prowadził wykłady także w Studium Homiletycznym i Studium Katechumenalnym (1991-1992), w Wyższym Seminarium Duchownym Archidiecezji Krakowskiej (1991) i na Wydziale Historii Kościoła (1992-1994, wykłady zlecone). Od 1992 r. prowadzi wykłady kursoryczne i ćwiczenia z liturgiki oraz seminarium naukowe w Wyższym Seminarium Duchownym Braci Mniejszych (OFM) w Krakowie-Bronowicach. W roku 1994 został powołany na członka Komisji ds. Liturgii II Polskiego Synodu Plenarnego Konferencję Episkopatu Polski. Od 1 października 1994 r. (pełny etat) pracuje na Wydziale Historii Kościoła Papieskiej Akademii Teologicznej w Krakowie (Uniwersytet Papieski Jana Pawła II w Krakowie, Wydział Historii i Dziedzictwa Kulturowego). Od 1990 r. jest członkiem Koła Naukowego Wykładowców Liturgiki przy Papieskiej Akademii Teologicznej w Krakowie oraz należy do grona Wykładowców Liturgiki w Ośrodkach Uniwersyteckich, Akademiach, Wydziałach Teologicznych i Wyższych Seminariach Duchownych (Sekcja Wykładowców Liturgiki przy Komisji Episkopatu Polski ds. Nauki). W latach 2000-2007 prowadził wykłady kursoryczne i ćwiczenia z liturgiki oraz seminarium naukowe na Wydziale Pedagogiki Wyższej Szkoły Filozoficzno-Pedagogicznej Ignatianum w Krakowie, oddział w Sosnowcu. W latach 2000-2006 prowadził wykłady kursoryczne (IV i V rok) w Wyższym Seminarium Duchownym Franciszkanów Konwentualnych (OFM Conv) w Krakowie. W latach 2007-2013 prowadził wykłady z liturgiki w Wyższym Seminarium Duchownym w Kielcach (Wydział Teologii Katolickiego Uniwersytetu Lubelskiego) ${ }^{2}$.

Jego praca naukowa jest bardo znacząca. Tylko pobieżne zestawienie ukazuje, że w latach 1977-2016 opublikował 18 monografii naukowych, ponadto dwóch

\footnotetext{
1 Wszystkie informacje pochodzą z archiwum własnego ks. Jana Józefa Janickiego.

2 Tamże.
} 
jest współautorem. Poza już tutaj wymienionymi trzeba przywołać: U początków liturgii Kościota (Kraków 2002), Kultury antyczne w liturgii chrześcijańskiej (Kraków 2003), Święci chwatą Krakowa (Kraków 2010), Stużba Boża w pierwszych wiekach Kościota. Wybrane zagadnienia (Kraków 2011), Świętymi bądźcie! Postuga uświęcania w Kościele (Kraków 2015). Ukazało się drukiem przeszło 100 jego artykułów naukowych, w których odnajdziemy wszystkie właściwie tematy, i tu jedynie dla przykładu podać warto: Teologia modlitw za zmartych $w$ Mszale Rzymskim Pawta VI i w Liturgii Godzin (Kielce 1979), Teologia modlitw w odnowionej liturgii Sakramentu Chorych (Łódź 1981), Sens i rola hymnów („Ateneum Kapłańskie” 1983), Elementy sktadowe Liturgii Godzin (Kraków 1984), Eucharystia - centrum i wypetnienie misterium paschalnego (Kraków 1993), Sakramentalia i btogostawieństwa wedtug nowego Katechizmu Kościota katolickiego (Opole 1995), Katechizm Kościota katolickiego o sakramencie matżeństwa (Warszawa 1995), Sakramentarz gelazjański (Reginensis latinus 316). Zarys roli i znaczenia najstarszego mszatu Kościoła (Kraków 1997/1998), Święto Paschy. „Uroczystość nad uroczystościami” (Sandomierz 1999), Postuga uświęcania (Lublin 2002), „Instaurare omnia in Christo” papieża św. Piusa X (1903-1914) - a odnowa liturgiczna (Kraków 2004), Burkhard Neunheuser OSB (1903-2003). Homo paschalis (Kielce 2008), Liturgia - życiem Kościoła w nauczaniu św. Jana Pawta II (Kielce 2010), Nowy katolicki modlitewnik i śpiewnik jezzyka niemieckiego Gotteslob. Katholisches Gebet-und Gesangbuch (Kraków 2016). Wydał również 30 artykułów w pracach zbiorowych. Napisał 60 haseł encyklopedycznych oraz przeszło 200 artykułów popularnonaukowych. Był redaktorem 14 prac zbiorowych, a także wziął udział w niezliczonej ilości sympozjów i konferencji naukowych w Polsce i za granicą ${ }^{3}$.

Niezwykle ważne jest dla Jubilata promowanie kadry naukowej i duszpasterskiej. Tutaj wymienić szczegółowo należy promocje doktorskie, a mianowicie: mgr lic. Eligiusz Ryszard Dymowski OFM, I ministeri laicali nellecclesiologia di Y. M. J. Congar Postugi wiernych świeckich w eklezjologii Y. M. J. Congar, Kraków 2001; mgr lic. Franciszek Szajer OFM, Życie religijne i spoteczne Kościota katolickiego w Norwegii w latach 1945-2003, Kraków 2005; mgr lic. Stanisław Mieszczak SCJ, La Risurrezione di Cristo e la risurrezione con Cristo nell'innografia del Triodion e del Pentecostarion, Kraków 2011. Pod jego kierunkiem napisano przeszło 100 licencjatów i magisteriów. Był wiele razy recenzentem prac magisterskich, doktorskich i habilitacyjnych oraz w procedurze o nadanie tytułu profesora ${ }^{4}$.

Kierunki badań naukowych Księdza Profesora Jana Józefa Janickiego koncentrują się wokół następujących zagadnień: teologii liturgii (podstawowe rzeczywistości

$\begin{array}{ll}3 & \text { Tamże. } \\ 4 & \text { Tamże. }\end{array}$ 
liturgiczne, teologia tekstów euchologijnych nowych ksiąg liturgicznych Kościoła, misterium paschalne i jego uobecnienie w Eucharystii i w roku liturgicznym); historii liturgii (wpływy kultury hebrajskiej, helleńskiej i rzymskiej na liturgię chrześcijańską, liturgia pierwszych wieków Kościoła, dzieje ksiąg liturgicznych); historii lat świętych - jubileuszowych (historia ruchu liturgicznego, historia kongresów eucharystycznych, rola świętych w życiu Kościoła w świetle formularzy mszalnych); duszpasterstwa liturgicznego (liturgia wypełnianiem posługi uświęcania we wspólnocie Kościoła, posługa zakrystiana, liturgia w Ziemi Świętej).

Za swoją pracę otrzymał liczne nagrody i wyróżnienia oraz medale państwowe i godności kościelne. Medal srebrny za długoletnią służbę, odznaczenie od Prezydenta Rzeczypospolitej Polskiej Lecha Kaczyńskiego w 2009 r. Medal Jana Pawła II brązowy za zasługi dla Archidiecezji Krakowskiej w 2016 r. Nagroda Rektora Papieskiej Akademii Teologicznej w Krakowie za wybitne i twórcze osiągnięcia naukowe, dydaktyczne i organizacyjne w Akademii w 2006 r. Nagroda jubileuszowa Rektora Uniwersytetu Papieskiego Jana Pawła II w Krakowie z okazji 35-lecia pracy zawodowej w 2011 r. Nagroda jubileuszowa Rektora Uniwersytetu Papieskiego Jana Pawła II w Krakowie z okazji 40-lecia pracy zawodowej w 2016 r. Ponadto otrzymał dyplom nadany przez Zarząd Okręgu Polskiego Związku Filatelistów w Kielcach jako wyraz wdzięczności, uznania i podziękowania za aktywną, społeczną i wieloletnią działalność dla rozwoju polskiej filatelistyki w $1998 \mathrm{r}$. Nominacja na kanonika honorowego Kapituły Kolegiackiej przy Bazylice Mniejszej w Miechowie od biskupa kieleckiego Kazimierza Ryczana 22 grudnia 2001 r. Powołanie na członka Komisji Polskiej Akademii Umiejętności 17 lutego 2006 r. Cieszy się nadto srebrną odznaką honorową Polskiego Związku Filatelistów otrzymaną od Zarządu Okręgu Polskiego Związku Filatelistów w Kielcach w 2007 r. (napisał wiele artykułów na tematy filatelistyczne). Srebrna honorowa odznaka Ludowych Zespołów Sportowych od Prezydium Rady Wojewódzkiej Zrzeszenia LZS w Krakowie za zasługi położone dla rozwoju kultury fizycznej i turystyki na wsi otrzymaną 1 lipca 2013 r. ${ }^{5}$

Wydaje się, że drogę „pisania sercem liturgii” w Księdzu Profesorze Janie Józefie zaszczepił jeden z najważniejszych teologów i historyków liturgii po Vaticanum II, a był nim benedyktyński mnich z opactwa Maria Laach o prof. Burkhard Neunheuser $^{6}$. Ten wyjątkowy człowiek, profesor Pontificio Istituto Liturgico w Rzymie,

\footnotetext{
5 Tamże.
}

6 Prof. Burkhard Neunheuser OSB urodził się 12 grudnia 1903 r. w Essen, a zmarł 29 listopada 2003 r. w Maria Laach. W 1922 r., po przeniesieniu się z rodzicami do Düsseldorfu, mając 19 lat, wstąpił do benedyktyńskiego klasztoru Maria Laach. W latach 1925-1930 odbył studia w Rzymie z zakresu dogmatyki i liturgiki. W latach 1930-1937 wykładał w Wyż- 
stał się mentorem i wskazującym kierunek dla rozwoju naukowego naszego jubilata. Nieprzypadkowo pewnie swoistego rodzaju homagium dla Mistrza zakończył jubilat, stwierdzając, że to, co napisał, stanowi ,jedynie próbę «naszkicowania» postaci wielkiego teologa i liturgisty, jakim był (i jest!) dla każdego, kto jest liturgice cultor et amator - o. prof. Burkhard Neunheuser (1903-2003) - homo paschalis"7. To tylko więc próba, bo nie da się napisać wszystkiego, co się chce, tylko wówczas, gdy ogarnia człowieka świadomość ważności i wielkiego znaczenia kogoś lub czegoś, o kim i o czym się pisze. Może też i w tym kryje się tajemnica nadziei i dobroci Księdza Profesora Jana Józefa Janickiego - poza wychowaniem w rodzinnym domu i kształtowaniem duchowym przez dar i tajemnicę święceń, skoro jego także, podobnie jak Mistrza - najważniejszym dziełem jest pisanie i opowiadanie oraz nadzieja płynąca z misterium paschalnego Jezusa Chrystusa. To „ślad”, który z pewnością jest ważny, jak myślę, dla Jubilata.

Prawie 100 lat żyjący o. Burkhard, jako „człowiek Paschy”, wprowadzał swoich uczniów w znaczenie i teologię liturgii oraz zapisał się w ich pamięci jako: „świadek, uczestnik i wybitna postać ruchu liturgicznego, jeden ze znamienitych twórców odnowy liturgicznej XX wieku" ${ }^{8}$. Zmarł 29 listopada 2003 r., w 80. roku profesji zakonnej, 76. roku kapłaństwa i dwa tygodnie przed kolejnymi urodzinami. Pogrzeb zaś odbył się 3 grudnia 2003 r., można by powiedzieć, że w przededniu 40. rocznicy uchwalenia Konstytucji o Liturgii (4 XII 1963) ${ }^{9}$. Ale popatrzmy na początki, gdy „w latach 1925-1930 B. Neunheuser odbył w Rzymie specjalistyczne studia z zakresu dogmatyki i liturgiki, uwieńczone zdobyciem stopnia doktora [...] po powrocie ze studiów rzymskich, od początku lat trzydziestych (19301937), został docentem w Wyższej Szkole Filozoficznej w opactwie Maria Laach, a przez dwa lata (1937-1939), jako profesor nadzwyczajny wykładał teologię dogmatyczną w Papieskim Ateneum „San Anselmo” na Awentynie w Rzymie” ${ }^{10}$. Po II wojnie światowej angażował się w życie naukowe i duszpasterskie w Maria Laach, zwłaszcza w pracę wśród młodzieży. Od 1962 r. został profesorem Instytutu Liturgicznego (był także jego rektorem do 1978 r.). Wykładał na Urbanianum

szej Szkole Filozoficznej w Maria Laach. W latach 1937-1939 wykładał teologię dogmatyczną w Papieskim Ateneum „San Anselmo” w Rzymie. Od 1962 r. profesor (do 1978 r. rektor) Papieskiego Instytutu Liturgicznego w Rzymie. Zob. J. J. Janicki, Burkhard Neunheuser OSB (1903-2003). Homo paschalis, „Kieleckie Studia Teologiczne” 7 (2008), s. 43-66.

7 J. J. Janicki, Burkhard Neunheuser OSB..., dz. cyt., s. 65.

8 J. J. Janicki, Burkhard Neunheuser OSB..., dz. cyt., s. 43.

9 Piszący te słowa we wrześniu 2003 r. miał możliwość spotkania z tym wybitnym mistrzem teologii i historii liturgii w opactwie Maria Laach w Niemczech podczas swojego stypendium habilitacyjnego w roku akademickim 2003/2004.

10 J. J. Janicki, Burkhard Neunheuser OSB..., dz. cyt., s. 45-46. 
oraz Gregorianum. Papież Paweł VI powołał go do Rady Papieskiej, która miała wprowadzać reformę liturgiczną w codzienną praktykę Kościoła. Wykształcił wielu wybitych liturgistów dla Kościoła w Polsce, by wspomnieć jedynie tych ze środowiska krakowskiego: o. Franciszka Małaczyńskiego OSB, ks. Wacława Świerzawskiego, ks. Jana Józefa Janickiego.

Nie można tutaj nie zauważyć, że 21 października 1992 r. Senat i Rektor Papieskiej Akademii Teologicznej w Krakowie nadali ojcu profesorowi godność doktora honoris causa. Wówczas wygłosił on wykład na temat znaczenia misterium paschalnego w teologii Soboru Watykańskiego II i życiu Kościoła posoborowego. „Profesor prosił słuchaczy, aby przyjęli jego wystąpienie jako "przyznanie się do tego świata teologicznego, który mój klasztor Sanctae Mariae ad Lacum (Maria Laach) dał mi jako fundament na lata wykładów na Papieskim Instytucie Liturgicznym św. Anzelma w Rzymie»" "11. Właśnie na tym wykładzie nowy doktor honoris causa rozważał także różnicę pomiędzy liturgiką a liturgią. Mówił:

liturgia jest czynnością święta wypełnioną przez Ducha Świętego i prowadzoną przez Niego, jest czynnością, w której obecny jest Chrystus darujący jej uczestnikom obecność dzieła zbawczego, jest ona sprawowaniem myserium danym jako zadanie przez Jezusa Chrystusa, a rozwijanym w ciagu wieków przez tych, którzy to zadanie otrzymali, a więc przez Apostołów i ich następców. Wielkie rzeczy dokonują się w liturgii mocą Ducha Świętego i dzięki obecności Chrystusa, ale także poprzez wiarę jej uczestników będącą odpowiedzią na Boskie działanie. Konstytucja o liturgii wzywa do wiary i do odpowiedniej dyspozycji uczestników liturgii ${ }^{12}$.

Zwracał też uwagę na rozwój liturgiki i jej wielki wkład w celebrację sakramentów. W zaistniałym zaś czasie, po ogłoszonej soborowej reformie liturgii, niezwykle ważne była i jest ,sumienna i solidna praca wykonana przez kompetentnych liturgistów. Realizacja dzieła odnowy w poszczególnych krajach domaga się również dalszej pracy naukowej. Tu wykazują się pracą instytuty liturgiczne” - i kończąc swoje wystąpienie, stwierdzał: „liturgika jako nauka nie tylko pomaga w lepszym sprawowaniu liturgii, leczy liturgia stanowi dla niej fundament i punkt wyjścia do jej badań. Tak w dziedzinie teologii liturgii, jak w dziedzinie historii liturgii wiele pozostaje do zrobienia. Stale musi liturgika z jej naukową akrybią przyczyniać się do lepszego sprawowania liturgii jako świętej czynności przed Bogiem w Chry-

11 J. J. Janicki, Burkhard Neunheuser OSB..., dz. cyt., s. 47.

12 B. Neunheuser, Liturgie Und Liturgiewissenschaft, tłum. S. Cichy, Kraków 1993, s. 29. 
stusie" ${ }^{13}$. Niezwykle więc ważna, a zarazem znacząca była ta wizyta Mistrza liturgiki i mystagoga liturgii posoborowej w Krakowie, także jako obecność „świadka” dokonywanych zmian w Kościele powszechnym. Ale można powiedzieć, że był to też sposób spłacenia „długu” za wkład w kształtowanie umysłów późniejszych „Mistrzów liturgiki” w środowisku wpierw Instytutu Liturgicznego, a dzisiaj na Uniwersytecie Papieskim Jana Pawła II w Krakowie, w tym także naszego Jubilata.

Kluczowe dla nauczania o soborowej liturgii przez o. Neunheusera było zwrócenie uwagi na misterium paschalne, które jest centrum roku liturgicznego i każdej czynności Kościoła. To bowiem Męka, Śmierć i Zmartwychwstanie oraz Wniebowstąpienie Chrystusa, przez które właśnie dokonują się najważniejsze „cuda”, a są to uwielbienie Boga i odkupienie człowieka (zob. KL 5, 6). To wydarzenie centralne w historii zbawienia ${ }^{14}$. Dlatego też:

zbawcze działanie Chrystusa „z Jego szczytowym dopełnieniem, dokonywanym raz na zawsze w misterium paschalnym, staje się - przez liturgię fundamentalną wartością chrześcijańskiego życia”; misterium paschalne Chrystusa stanowi centralne wydarzenie życia Kościoła. Ta wiara Kościoła nakazywała wspominać i uobecniać, „przez cały rok”: „zbawcze dzieło Syna Bożego” - „całe misterium Chrystusa” - „misteria Odkupienia” (por. KL 102), których momentem węzłowym jest misterium paschalne Chrystusa. Dlatego też wokół tajemnicy paschalnej koncertuje się całoroczne życie Kościoła ${ }^{15}$.

Może też właśnie racja, że trzeba żyć nieustannie w radości misterium paschalnego, co było dewizą życia i działalności niemieckiego benedyktyna, stała się zaszczepionym ziarnem w jego uczniach. Dlatego też słusznym jest przypomnienie, że:

celem fundamentalnym reformy liturgicznej było i jest, aby w życiu Kościoła, w życiu wiernych wyraziło się misterium paschalne, realizowane i aktualizowane (uobecniane) w liturgii, która jest dziełem Chrystusa-Kapłana i Jego Ciała, czyli Kościoła. Celebracja liturgiczna jest „czynnością w najwyższym stopniu świętą, a żadna inna czynność Kościoła nie dorównuje jej skuteczności z tego samego tytułu i w tym samym stopniu" (KL 7).

13 B. Neunheuser, Liturgie Und Liturgiewissenschaft, dz. cyt., s. 30.

14 Zob. B. Neunheuser, Il mistero pasquale „culmen et fons” dell'anno liturgico, „Rivista Liturgica" 62 (1975) nr 2, s. 151.

15 J. J. Janicki, Burkhard Neunheuser OSB..., dz. cyt., s. 48. Zob. J. J. Janicki, U początków liturgii Kościota, Kraków 2002, s. 137-141. 
Misterium paschalne ma być tak wyrażone, aby całe nasze życie stało się życiem in Christo Jesu $u$ in laudem gloriae Dei ${ }^{16}$.

Bowiem najgłębszą treścią każdej liturgicznej celebracji jest właśnie misterium paschalne.

Tu oczywiście możemy mówić o odniesieniu do dzieł i nauczania nie tylko o. Neunheusera, ale zasadniczo i zupełnie fundamentalnie do samego o. Odo Casela $^{17}$, bowiem to właśnie on stoi u początków takiegoż myślenia i nauczania tzw. n a u k o miste riach, bowiem nikt lepiej jak ten właśnie mystagog nie stał się Mistrzem poszukiwania misterium w celebracjach liturgicznych po Soborze Watykańskim II.

Trzeba tutaj też przypomnieć, że benedyktyńskie opactwo Maria Laach już od 1918 r. było miejscem ożywionych teologicznych dyskusji na temat teologii liturgii $^{18}$. Odo Casel wprowadzał wiernych w tajemnicę liturgii i życia. Liturgiczna celebra według niego była uobecnieniem „stającego się dzieła zbawienia” " ${ }^{19}$. Zaś napis na jego nagrobku oddaje treść jego życia: „śpiewając hymn paschalny i wyznając pełnym głosem Światłość Chrystusa, o dr Odo Casel, mnich z opactwa Maria Laach, mystagog i czciciel Świętego Misterium po dopełnieniu ofiary, przemieniony paschalnymi misteriami, w które sam innych wtajemniczał, przeszedłszy z Panem w Wielką Noc, wszedł do uszczęśliwiającego widzenia. Bogu niech będą dzięki”"

$\mathrm{O}$ nauczaniu o. Casela napisano bardzo wiele, ja jednak odniosę się w tym miejscu tylko do jednego wystąpienia o. Neunheusera, które przesłał - bo sam nie

16 J. J. Janicki, Burkhard Neunheuser OSB..., dz. cyt., s. 50-51. Zob. J. J. Janicki, Świętymi bądźcie! Postuga uświęcania w Kościele, Kraków 2015, s. 19-22.

17 Odo Casel OSB, urodzony 27 września 1886 r. w Koblencji, zmarł 28 marca 1948 r. w Harstelle. Benedyktyn z klasztoru Maria Laach w Niemczech. Twórca misteryjnej teorii w sakramentach. Do zakonu wstąpił w 1905 r. w Maria Laach, święcenia kapłańskie przyjął w 1911 r. W latach 1908-1912 studiował teologię na Anselmianum w Rzymie, gdzie uzyskał doktorat, a w latach 1913-1918 studiował filologię w Bonn. W latach 1921-1941 był redaktorem czasopisma „Jahrbuch für Liturgiewissenschaft”. Prowadził studia z zakresu liturgiki i sakramentologii (zwłaszcza Eucharystii). Ogłosił wiele dzieł na ten temat. Zob. R. Goczoł, Casel Odo, Encyklopedia katolicka, t. 2, kol. 1350-1351; R. Tyrała, Cecyliański ruch odnowy muzyki kościelnej na ziemiach polskich do 1939 roku, Kraków 2010, s. 27-28.

18 Zob. B. Neunheuser, Movimento liturgico, w: Nuovo Dizionario di Liturgia, a cura di D. Sartore, A. M. Triacca, Milano 1988, s. 847-856.

19 B. Neunheuser, Wstęp, w: O. Casel, Mysterium der Ecclesia, Mainz 1961, s. 16.

20 W. Świerzawski, Odo Casel - mystagog i teolog 1886-1948, „Ruch Biblijny i Liturgiczny” 6 (1878), s. 318-319. Zob. R. Tyrała, Cecyliański ruch odnowy muzyki kościelnej na ziemiach polskich do 1939 roku, Kraków 2010, s. 28. 
mógł być obecny - na sympozjum w Krakowie organizowanego z okazji 100-lecia urodzin Odo Casela w 1988 r. $^{21}$

Misterium w kulcie, bowiem o takim zagadnieniu jest tutaj mowa, jest „najpierw działaniem Boga, realizacją odwiecznego planu Bożego w działaniu [...] w szerszym rozwinięciu słowa "Misterium Chrystusa» ujmuje Casel całość «Oikonomia», Boży plan zbawienia człowieka i jego urzeczywistnienie w Chrystusie"22. I właśnie skoro Boży plan zbawienia urzeczywistnia się w Chrystusie, to w centrum chrześcijaństwa znajduje się Pascha, czyli ofiara. W tym zaś wszystkim „Kościół bierze aktywny udział w Jego ofierze, Jego ofiarę czyni swoją ofiarą i przez niego zostaje podniesiony z tego świata do Boga oraz uwielbiony" ${ }^{23}$. To zaś uczestnictwo w ofierze jest dziełem łaski, potrzebna jest więc wiara, a wszystko dokonuje się w misterium kultu. By człowiek mógł przyjąć Bożą łaskę, dlatego też potrzebny jest ów kult, bowiem wszystko to, co w nas się dokonuje, „poprzez te święte czynności staje się rzeczą możliwą to, że my uczestniczymy w zbawczych czynach Chrystusa” ${ }^{24}$. Ale tutaj można iść jeszcze nieco dalej, „uczestnictwo chrześcijanina w zbawczym dziele Chrystusa możliwe jest dlatego, że to zbawcze dzieło Pana jest obecne w sakramentach, czyli w misterium, i że obie te rzeczywistości: działanie Chrystusa i nasze uczestnictwo w nim, są ze sobą ściśle powiązane właśnie poprzez słowo mysterion, któremu odpowiada tłumaczenie łacińskie sacramentum" ${ }^{25}$. I tu pewnie jest niezwykle ważne stwierdzenie, że to, co historycznie zostało dokonane, nie jest jedynie pamiątką, ale rzeczywistością nowego życia, które udzielane jest chrześcijanom właśnie w tym momencie, tu i teraz. Właśnie owa rzeczywistość jest „obecnością misterium”. I dlatego „chrześcijańska liturgia jest rytualnym urzeczywistnieniem zbawczego dzieła Chrystusa w Kościele i przez Kościół. Jest więc ona obecnością Boskich czynów zbawczych Chrystusa pod zasłoną znaków”26. Ten zaś znak jest symbolem rzeczywistym, nic nie dodaje do ofiary już raz na zawsze złożonej, jest wspomnieniem tej rzeczywistości obiektywnej i realnej. Obecność misteryjna jest realna we wszystkich sakramentach. Toteż wyraźnie można powiedzieć, że cała nauka Odo Casela miała wielki wpływ na nauczanie o liturgii i o sakramentach Soboru Watykańskiego II ${ }^{27}$. Konkludując, o. Neunhouser pisał:

21 Publikacja ze sympozjum z okazji 100-lecia urodzin Odo Casela w „Ruch Biblijny i Liturgiczny" 2(1988).

22 B. Neunheuser, Problem obecności misterium w liturgii $w$ dzietach O. Casela, „Ruch Biblijny i Liturgiczny" 2 (1988), s. 131.

23 B. Neunheuser, Problem obecności misterium..., dz. cyt., s. 131.

24 B. Neunheuser, Problem obecności misterium..., dz. cyt., s. 131.

25 B. Neunheuser, Problem obecności misterium..., dz. cyt., s. 132.

26 B. Neunheuser, Problem obecności misterium..., dz. cyt., s. 132.

27 Zob. B. Neunheuser, Problem obecności misterium..., dz. cyt., s. 134-135. 
wolno nam powiedzieć, że dana jest nam w liturgii eucharystycznej autentyczna „obecność”, mocą której uczestniczymy czynnie w zbawczym dziele Chrystusa, biorąc udział w świętych czynnościach dla kształtowania siebie samych na wzór Chrystusa i osiągnięcia zbawienia i to już teraz na ziemi, w nadziei na jego wypełnienie w wiecznym Królestwie Chrystusa u Ojca w Duchu Świętym ${ }^{28}$.

To jest więc doświadczenie rzeczywistości przyszłej oczyma wiary.

Wszystko to, czemu służyli przez całą historię odnowy liturgii wielcy jej piewcy tej miary co dom Prosper Gueranger, Pius Parch, Odo Casel, Romano Guardini i inni, a także Burkhard Neunheuser, było niezwykle ważne dla tego, aby „misterium paschalne wkorzenić w życie człowieka” ${ }^{29}$. I dlatego wydaje się, że tu znajduje się owa nić, która łączy tych własnie wielkich i wspaniałych liturgistów z naszym Jubilatem, który głosi z wielkim powodzeniem misterium paschalne. Nic więc dziwnego, że w 1992 r. ukazuje się jego ważna książka Misterium Paschalne ${ }^{30}$, w której wykłada całościowo naukę dotyczącą tego zagadnienia. W zakończeniu zaś zapisał:

uroczystości paschalne przywracają Kościołowi „młodość ducha”, napełniając go mocą i siłą Kościoła pierwszych wieków. Rzeczywistość ta dokonuje się poprzez umocnienie w naszych sercach ducha przybranych dzieci; Bóg daje swemu ludowi poznać tajemnicę zmartwychwstania Swego Syna i pozwala mu powstawać do nowego życia. Napełnienie wiernych łaską przeżywanego misterium Chrystusa sprawia ich przejście ze „starości” do „nowości” źycia. Doroczna uroczystość paschalna stanowi umocnienie wiary jako fundamentu życia chrześcijańskiego i napełnia nadzieją oczekiwanie chwalebnego dnia zmartwychwstania ${ }^{31}$.

To pewnie też jest sensem i siłą nadziei naszego Jubilata.

28 B. Neunheuser, Problem obecności misterium..., dz. cyt., s. 135.

29 B. Neunheuser, Sto lat ruchu odnowy liturgicznej zapoczatkowanego przez o. Prospera Gueranger. Przesztość i perspektywy, „Ruch Biblijny i Liturgiczny” 4 (1976), s. 207.

30 Zob. J. J. Janicki, Misterium paschalne..., dz. cyt.

31 J. J. Janicki, Misterium paschalne..., dz. cyt., s. 232. 


\section{Streszczenie}

Liturgia sercem pisana! Ks. prof. dr hab. Jan Józef Janicki i jego Mistrzowie

Skoro „liturgia jest źródłem i szczytem życia Kościoła” (KL 10), jak naucza nas Sobór Watykański II, to z niej wszystko wypływa i do niej wszystko zdąża. O takim właśnie rozumieniu tej „cząstki” życia Kościoła niezwykle przekonany jest Jubilat, który dla piękna tej szaty Kościoła, jaką jest liturgia, poświęcił swoje naukowe i życiowe dociekania, dlatego można powiedzieć o nim, że liturgię sercem pisał! Kierunki badań naukowych Księdza Profesora Jana Józefa Janickiego koncentrują się wokół następujących zagadnień: teologii liturgii (podstawowe rzeczywistości liturgiczne, teologia tekstów euchologijnych nowych ksiąg liturgicznych Kościoła, misterium paschalne i jego uobecnienie w Eucharystii i w roku liturgicznym); historii liturgii (wpływy kultury hebrajskiej, helleńskiej i rzymskiej na liturgię chrześcijańską, liturgia pierwszych wieków Kościoła, dzieje ksiąg liturgicznych); historii lat świętych - jubileuszowych (historia ruchu liturgicznego, historia kongresów eucharystycznych, rola świętych w życiu Kościoła w świetle formularzy mszalnych); duszpasterstwa liturgicznego (liturgia wypełnianiem posługi uświęcania we wspólnocie Kościoła, posługa zakrystiana, liturgia w Ziemi Świętej). Wydaje się, że całkowitą drogę „pisania sercem liturgii” zaszczepił mu jeden z najważniejszych teologów i historyków liturgii po Vaticanum II, a był nim benedyktyński mnich z opactwa Maria Laach o prof. Burkhard Neunheuser. Ten wyjątkowy człowiek, profesor Pontificio Istituto Liturgico w Rzymie, stał się mentorem i wskazującym kierunek dla rozwoju naukowego naszego Jubilata.

Kluczowe dla nauczania o soborowej liturgii przez o. Neunheusera było zwrócenie uwagi na misterium paschalne, które jest centrum roku liturgicznego i każdej czynności Kościoła. To bowiem Męka, Śmierć i Zmartwychwstanie oraz Wniebowstąpienie Chrystusa, przez które właśnie dokonują się najważniejsze „cuda”, a są to uwielbienie Boga i odkupienie człowieka (zob. KL 5, 6). To jest wydarzenie centralne w historii zbawienia. Skoro Boży plan zbawienia urzeczywistnia się w Chrystusie, to w centrum chrześcijaństwa znajduje się Pascha, czyli ofiara. Kościół bierze aktywny udział w Jego ofierze, Jego ofiarę czyni swoją ofiarą i przez niego zostaje podniesiony z tego świata do Boga oraz uwielbiony. To zaś uczestnictwo w ofierze jest dziełem łaski, potrzebna jest więc wiara, a dokonuje się to w misterium kultu. Wszystko to, czemu służyli przez całą historię odnowy liturgii wielcy jej piewcy tej miary co dom Prosper Gueranger, Pius Parch, Odo Casel, Romano Guardini i inni, a także Burkhard Neunheuser, było niezwykle ważne dla tego, aby misterium paschalne wkorzenić w życie człowieka. I dlatego wydaje się, że tu znajduje się owa nić, która łączy tych wielkich i wspaniałych liturgistów z naszym Jubilatem, który głosi $\mathrm{z}$ dużym powodzeniem misterium paschalne. 
Stowa kluczowe: liturgia źródłem i szczytem życia Kościoła, ks. Jan Józef Janicki, misterium paschalne, o. Burkhard Neunheuser, o. Odo Casel, Męka, Śmierć i Zmartwychwstanie oraz Wniebowstąpienie Chrystusa, liturgia, mystagogia

\section{Summary}

According to the teaching of Vatican Council II: "liturgy is the summit toward which the activity of the Church is directed [...] and the font from which all her power flows" (SC 10). This meaning of "a particle" of Church life is what Rev. Prof. Jan Józef Janicki, celebrating now his jubilee, is so much convinced that he has devoted to liturgy, this beautiful Church attire, his entire scientific and life pursuits, writing about it with all his heart! The scientific research of Rev. Prof. Janicki has focused on the following issues: theology of liturgy (basic liturgical realities, theology of euchological texts of the new liturgical books of the Church, Paschal Mystery and its expression in the Eucharist and in liturgical year); history of liturgy (the influence of the Hebrew, Hellenistic and Roman cultures on the Christian liturgy, the liturgy of the first centuries of the Church, history of liturgical books); history of holy and jubilee years (history of liturgical movement, history of liturgical congresses, the role of Saints in the Church life in the light of Mass formulas); liturgical ministry (liturgy as exercising the ministry of sanctification in the Church community, the ministry of a sacristan, liturgy of the Holy Land). It appears that the entire way of "writing liturgy with his heart" was implanted in Rev. Prof. Janicki by one of the most acclaimed theologians and historians of post Vatican Council II period, the Benedictine monk from Maria Laach Abbey, Professor Burkhard Neunheuser. This remarkable man, the professor of Pontificio Istituto Liturgico in Rome, became Rev. Prof. Janicki's mentor guiding him and showing the path for his academic growth.

The key idea in Fr. Neunheuser's post-Council teachings about liturgy was emphasizing the role of the Paschal Mystery which is the very centre of liturgical year and of each Church activity. Therefore, Passion, Death and Resurrection as well as the Ascension of Christ are these events through which the most important "miracles" are done, namely, adoration of God and redemption of man (cf. SC 5,6). These are the pivotal moments in the history of salvation, as God's plan is realized in Christ, and the centre of Christianity is Pascha, the sacrifice. The Mother Church takes an active part in His sacrifice, making His sacrifice her own, and by Him she is raised from this world up to God and praised. This participation in Christ's sacrifice is the act of grace, so there must be belief, and everything is accomplished through the mystery of worship. Everything to which the greatest advocates of liturgy, such as, Prosper Gueranger, Pius Parch, Odo Casel, Romano 
Guardini and Burkhard Neunheuser amongst them devoted throughout the entire history of liturgy revival has been crucial to engrain the Paschal Mystery in man's life. Here we can find this thread which links all those magnificent liturgists with our honourable Rev. Professor Janicki who has been proclaiming so successfuly the Paschal Mystery.

Keywords: liturgy as the font and summit of Church life, Rev. Jan Janicki, Paschal Mystery, o. Burkhard Neunheuser, o. Odo Casel, Passion, Death and Resurrection, and Ascension of Christ, liturgy, mystagogy

\section{Bibliografia}

Goczoł R., Casel Odo, Encyklopedia katolicka, t. 2, kol. 1350-1351.

Janicki J. J., Burkhard Neunheuser OSB (1903-2003). Homo paschalis, „Kieleckie Studia Teologiczne" 7 (2008), s. 43-66.

Janicki J. J., Świętymi bądźcie! Postuga uświęcania w Kościele, Kraków 2015.

Janicki J. J., U początków liturgii Kościota, Kraków 2002.

Neunheuser B., Il mistero pasquale „culmen et fons” dell'anno liturgico, „Rivista Liturgica” 62 (1975) nr 2, s. 151.

Neunheuser B., Liturgie Und Liturgiewissenschaft, tłum. S. Cichy, Kraków 1993.

Neunheuser B., Movimento liturgico, w: Nuovo Dizionario di Liturgia, a cura di D. Sartore, A. M. Triacca, Milano 1988.

Neunheuser B., Problem obecności misterium w liturgii $w$ dzietach O. Casela, „Ruch Biblijny i Liturgiczny" 2 (1988), s. 131.

Neunheuser B., Sto lat ruchu odnowy liturgicznej zapoczątkowanego przez o. Prospera Gueranger. Przesztośc i perspektywy, „Ruch Biblijny i Liturgiczny” 4 (1976), s. 207.

Neunheuser B., Wstęp, w: O. Casel, Mysterium der Ecclesia, Mainz 1961.

Świerzawski W., Odo Casel - mystagog i teolog 1886-1948, „Ruch Biblijny i Liturgiczny” 6 (1878), s. 318-319.

Tyrała R., Cecyliański ruch odnowy muzyki kościelnej na ziemiach polskich do 1939 roku, Kraków 2010.

Tyrała R., Cecyliański ruch odnowy muzyki kościelnej na ziemiach polskich do 1939 roku, Kraków 2010. 